ELORE (ISSN 1456-3010), vol. 15 - 1/2008.

Julkaisija: Suomen Kansantietouden Tutkijain Seura ry.

[http://www.elore.fi/arkisto/1_08/sod1_08.pdf]

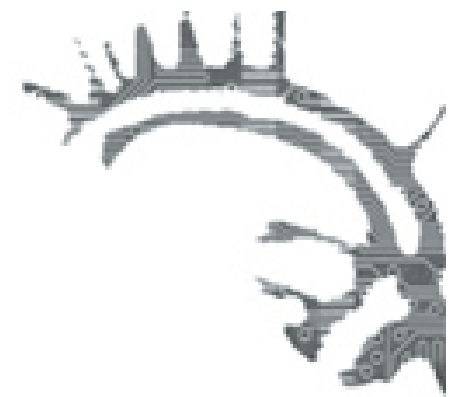

\title{
KIRJA-ARVIO:
}

\section{EETTISYYS JA IHMISTIETEIDEN KESTÄVÄ KEHITYS?}

Hallamaa, Jaana \& Launis, Veikko \& Lötjönen, Salla \& Löytty, Olli (toim.) 2006:

Etiikkaa ihmistieteille. Tietolipas 211. Helsinki: Suomalaisen Kirjallisuuden Seura. 426 sivua.

\section{Stig Söderholm}

Etiikkaa ihmistieteille tarjoaa laajan ja moniperspektiivisen katsauksen humanististen ja yhteiskuntatieteellisten alojen tutkimuskäytäntöjen problematiikkaan. Kirjan runsaat kaksikymmentä kirjoitusta, joista noin kolmannes on usean kirjoittajan yhteisartikkeleita, nostavat esiin tärkeitä kysymyksiä. Ne käsittelevät muiden muassa tiedeyhteisön toimintakulttuuria, sektoritutkimuksen erityisongelmia, yksilönsuojan kysymyksiä, tilastollisia aineistoja, laadullisia aineistoja, tieteellisen julkaisutoiminnan periaatteita. Omana osionaan käydään läpi hyvän tutkimuskäytännön institutionaalisia periaatteita.

Etiikkaa ihmistieteille on ilman muuta jokaisen ihmistä ja yhteiskuntaa tutkivan yliopistotyöntekijän peruslukemistoa. Mikään valmis, lopullinen normatiivinen ohjeistus se ei kuitenkaan ole. Tähän mahdottomuutta hipovaan legitimiteettiin ei ole edes pyritty, minkä voinee päätellä siitä, että kirjan johdantoartikkelin otsikkona on kirjan nimi, mutta nyt kysymysmerkillä varustettuna: "Etiikkaa ihmistieteille?" Kysymysmerkki on varmasti tarpeellinen, kun otetaan huomioon tälläkin hetkellä käynnissä oleva suomalaisen yliopistolaitoksen rakennemuutos ja siihen liittyvät uudet taloudelliset, kilpailulliset ja tuottavuuteen liittyvät vaateet.

\section{KESKUSTELU ETIIKASTA EI OLE UUSI ASIA}

Kirjan yhtenä tiedonintressinä on olemassa olevan puutteen täyttäminen. 'Humanististen ja yhteiskuntatieteiden etiikkaa koskevan keskustelun puute näkyy siinäkin, että 


\section{EETTISYYS JA IHMISTIETEIDEN KESTÄVÄ KEHITYS?}

näiden alojen etiikkaa käsittelevää kirjallisuutta ei toistaiseksi ole julkaistu suomeksi kovinkaan paljon" (s. 14), luonnehtivat toimittajat kirjansa taustaa. Tässä lähtökohdassa, ja erityisesti sen tutkimushistoriaan kurkottavissa perusteluissa on hiukan täydentämisen varaa, sillä "eettiset kysymykset ihmistieteissä" -teema ei ole millään tavoin vasta 1990-luvulla esiinnoussut asia. Erilaisissa keskustelukonteksteissa ja vaihtelevin terminologioin eettistä pohdintaa on harrastettu Suomen ihmistieteiden piirissä jo vuosikymmeniä. Kirjan toimittajat mainitsevat "suomalaisen tutkimusetiikan" uranuurtajana Tiede ja etiik.ka -teoksen (Löppönen et. al. 1991). Tämän maininnan myötä ihmistieteitä koskevan eettisen kirjoittamisen historia pätkäistään liioittelevan lyhyeksi. Suomessa esimerkiksi kulttuuriantropologit ja sosiologit käsittelivät ahkerasti omien tieteenalojensa eettisiä kysymyksiä ja ongelmia jo 1970- ja 1980-luvuilla. Anita Kelles julkaisi vuonna 1979 artikkelin "Antropologisen tutkimuksen eettisiä ongelmia" (vrt. myös Kelles-Viitanen 1982), jonka taustalla oli paljolti eräiden yhdysvaltalaisten kulttuuriantropologisten tutkimusprojektien taloudelliset taustakytkennät ja "salaiset" tiedonintressit. Ne nostattivat sittemmin vilkkaan keskustelun yhteiskuntatieteellisen tutkimuksen sosiaalisesta vastuusta ja tutkimuksen tekemisen etiikasta. Myös Martti Grönfors (1982) käsitteli perusteellisesti etnografiseen tutkimustapaan nivoutuvia eettisiä ongelmatilanteita.

Lukijan näkökulmasta ihmistieteiden eettistä problematiikkaa tematisoivan kirjoittamisen diakronista ja tutkimushistoriallista hahmottamista vaikeuttaa ja vääristää myös se, että monet varhaisemmat tutkimuksenteon eettistä ohjeistoa tarjoavat julkilausumat on viitteistetty kirjassa (s. 416-419) uusien sähköisten lähteiden kautta. Kuitenkin monet näistä teksteistä on alun perin, siis jo ennen internetaikakautta, julkaistu kirjoina ja artikkeleina; alkuperäisten julkaisuvuosien esiin kaivaminen auttaisi lukijaa hahmottamaan eettisten keskustelujen ajalliset ja yhteiskuntahistorialliset kontekstit.

\section{ETIIKKA JA YLIOPISTOYHTEISÖ}

Etiikkaa ibmistieteille -teoksen rakenne ja jäsentely on harmoninen. Kirjoituksissa vuorottelevat sopivasti eettisten periaatteiden institutionaalisen ja yhteisöllisen sääntelyn periaatteita valottavat kirjoitukset sekä tutkimuskäytäntöihin, tutkimustilannekohtaisiin aineistoihin ja metodisiin lähestymistapoihin keskittyvät artikkelit. Etiikka ja eettisyys itsessään otetaan jotenkin annettuina, minkä seurauksena käsite-kritiikki puuttuu lähes kokonaan kirjasta. Tällekin tarkastelukulmalle olisi ollut tarvetta, kun otetaan huomioon, että eettisyys-puhe saa erilaisia sävyjä ja merkityksiä tieteellisissä, uskonnollisissa, taloudellisissa, journalistissa ja arkisissa diskursseissa.

Hiukan kyynisesti voisi todeta, että varsin usein instituutiot, korporaatiot ja yksilöt alkavat puhua eettisyydestä silloin, kun omat virheet halutaan kieltää. Eettisyyden ja kaikenlaisen kestävän hyvän taakse piiloutuminen alkaa olla globaalitalouden aikakaudella niin yleinen käytäntö, että perustellusti voidaan kysyä, onko edes mahdollista että 2000-luvun yliopisto olisi irti tämänkaltaisesta eettisyyden käsitteen 


\section{Stig SöDERHOLM}

kaventumisesta ja - moraalisesti ilmaistuna - jopa täydellisestä vääristymisestä. En malta olla viittaamatta Bill Readingsin (1996) teokseen The University in Ruins, jossa kirjoittaja toteaa, että nyt, kun ihmistieteellinen tutkimus halutaan yhä kiinteämmin sitouttaa ja integroida poliittisiin ja taloudellisiin intresseihin, on tutkijoiden tehtävänä tarjota (kriittisten) kysymysten sijaan pelkästään poliittisesti korrekteja ja mieluiten valmiita vastauksia. Realistinen tulevaisuuskuva lienee se, että kun tutkimuksen eettistä sääntelyä tarpeeksi vahvistetaan, autonominen yliopisto on kohtapuolin enää vain yksi ääni markkinavoimien kuorossa.

Etiikkaa ibmistieteille toimii mainiosti tutkijan työkaluna sekä yliopisto-opetuksen lukemistona. Siinä mielessä kirja täyttää tehtävänsä oivallisesti. Se tuo sopivana sekoitelmana esiin akateemisen vapauden ja vastuun tiukentuvat reunaehdot. Nopeasykkeisessä yliopistomaailman muutosbuumissa kirjan päivitetylle versiolle alkaa todennäköisesti olla kysyntää heti 2010-luvun alussa.

\section{KirjallisuUs}

GRÖNFORS, MART'TI 1982: Kvalitatiiviset kenttätyömenetelmät. Porvoo: WSOY.

KELLES, ANITA 1979: Antropologisen tutkimuksen eettisiä ongelmia: akateemisesta kolonialismista vastuuseen ja vuorovaikutukseen. - Suomen Antropologi (4).

KELLES-VIITANEN, ANITA 1982: Antropologisen tutkimuksen eettisiä ongelmia: tutkijan ja tutkittavien välisistä suhteista. - Suojanen, Päivikki \& Saressalo, Lassi (toim.), Kulttuurin kenttätutkimus. Tampereen yliopiston kansanperinteen laitoksen julkaisu 9. Tampere: Tampereen yliopisto.

LÖPPÖNEN, PAAVO \& MÄKELÄ, PIRJO \& PAUNIO, KEIJO (toim.) 1991: Tiede ja etiikeka. Porvoo: WSOY.

READINGS, BILL 1996: The University in Ruins. Cambridge: Harvard University Press.

Filosofian tohtori, dosentti Stig Söderholm toimii kulttuuriantropologian lehtorina Joensuun yliopistossa. 